\title{
Lifelong learning in Sustainable Development Goal 4: What does it mean for UNESCO's rights-based approach to adult learning and education?
}

\section{Maren Elfert ${ }^{1}$ (1)}

Published online: 24 June 2019

(c) The Author(s) 2019

\begin{abstract}
This article, which draws on a review of primary and secondary literature, examines the role of a human rights-based approach to adult learning and education (ALE) in the context of the global Education 2030 agenda, which is aligned with the Sustainable Development Goals (SDGs) launched in 2015 by the United Nations. Whereas the Millennium Development Goals (MDGs) focused on primary education, the SDGs, through SDG 4 which is devoted to education, call on Member States to "ensure inclusive and equitable quality education and promote lifelong learning opportunities for all". The inclusion of lifelong learning has awakened hopes for a stronger role of ALE in global education agendas and policies. In principle, the ten targets of SDG 4 open up clear possibilities for ALE. However, the author cautions that there is cause for scepticism that ALE, in particular human rights-based ALE, will receive more attention under the SDGs than it did under the MDGs. The article is structured into three sections. The first section traces the emergence of a rights-based approach to adult education as an international paradigm, with particular attention given to the role of UNESCO. The second section discusses how the rights-based approach to adult education has been contested by other actors in the field of education for development. In the final section, the author draws on recent empirical data to reflect on the role of ALE in the age of the SDGs.
\end{abstract}

Keywords lifelong learning · adult learning and education (ALE) - Sustainable Development Goals (SDGs) · education as a human right · UNESCO · literacy

\section{Résumé}

Apprentissage tout au long de la vie dans l'Objectif 4 de développement durable : quelle importance pour l'approche de l'apprentissage et de l'éducation des adultes fondée sur les droits que préconise l'UNESCO ? - Cet article s'appuie sur une ana-

Maren Elfert

maren.elfert@kcl.ac.uk

1 School of Education, Communication \& Society, King's College London, London, UK 
lyse de la documentation scientifique primaire et secondaire pour examiner le rôle d'une approche de l'apprentissage et de l'éducation des adultes (AEA) fondée sur les droits fondamentaux, dans le contexte de l'agenda mondial Éducation 2030 rattaché aux Objectifs de développement durable (ODD) énoncés en 2015 par les Nations Unies. Alors que les Objectifs du millénaire pour le développement (OMD) étaient axés sur l'enseignement primaire, les ODD, à travers l'Objectif 4 consacré à l'éducation, appellent les États membres à « assurer l'accès de tous à une éducation de qualité, sur un pied d'égalité, et (à) promouvoir les possibilités d'apprentissage tout au long de la vie ». L'inclusion de l'apprentissage tout au long de la vie fait naître l'espoir d'un rôle renforcé de l'AEA dans les politiques et programmes mondiaux en matière d'éducation. En principe, les dix cibles de l'Objectif 4 ouvrent des possibilités explicites pour l'AEA. Mais l'auteure invite à être sceptique quant au fait que les ODD accorderont une plus grande importance que les OMD à l'AEA, en particulier à l'approche fondée sur les droits fondamentaux. L'article est structuré en trois sections. La première retrace l'émergence en tant que modèle mondial d'une approche de l'éducation des adultes fondée sur les droits, et met l'accent sur le rôle de l'UNESCO. La seconde section analyse comment l'approche de l'éducation des adultes fondée sur les droits est contestée par d'autres acteurs dans le domaine de l'éducation pour le développement. Dans la dernière section, l'auteure s'appuie sur les données empiriques récentes pour explorer le rôle de l'apprentissage et de l'éducation des adultes à l'heure des Objectifs de développement durable.

\section{Introduction}

This article examines the role of a human rights-based approach to adult learning and education (ALE) in the context of the global Education 2030 agenda, which is aligned with the United Nations Sustainable Development Goals (SDGs). The agenda was launched in 2015 under the title Transforming our world: The 2030 Agenda for Sustainable Development (UN 2015). Given the strong historical connection between lifelong learning and adult education, the call within SDG 4 to "ensure inclusive and equitable quality education and promote lifelong learning opportunities for all" has awakened hope among many for a stronger role of ALE in global education agendas and policies. As Aaron Benavot (2018, p. 5) observes, this is the first time that lifelong learning has been articulated as a development priority, and therefore represents a historic opportunity to raise the profile of ALE. The prominence of lifelong learning is particularly notable, as the previous development frameworks paid little attention to it (Torres 2002). The Millennium Development Goals (MDGs), which preceded the SDGs, focused on primary education, and the Education for All agenda (1990-2015) emphasised basic education, effectively prioritising universal primary education (Power 2015, p. 48; McGrath 2018, p. 50). In principle, the ten targets of SDG 4 open up clear possibilities for ALE (Incheon Declaration, WEF 2015). However, I will argue that there is cause for scepticism that ALE, and in particular human rights-based ALE, will receive more attention under the SDGs. 
The question guiding this article is: What does the prominence of lifelong learning in SDG 4 mean for the human rights-based approach to ALE? I will approach the question by looking back at the history of adult education from the perspective of the United Nations Educational, Scientific and Cultural Organization (UNESCO), which, since its inception in 1945, has been instrumental in expanding the right to education to include adult and lifelong learning and education. The article draws on a review of primary and secondary literature and is structured into three sections. The first section traces the emergence of the rights-based approach to adult education as an international paradigm, with particular attention given to the role of UNESCO. The second section discusses how the rights-based approach to adult education has been contested by other actors in the field of education for development. In the final section of the article, I draw on recent empirical data on ALE to reflect on the future of ALE in the age of the SDGs.

\section{UNESCO and the right to (adult) education and lifelong learning}

The right to education was enshrined in UNESCO's constitution within the formulation "education for all" (UNESCO 2018 [1945], p. 5). Three years later, in 1948, it was included in article 26 of the Universal Declaration of Human Rights (UN 1948). Article 26 formed part of "social, economic and cultural rights", which were newer, less recognised and more contested than civil and political rights (Morsink 2000). Adult education appears in Article 26 in the references to "education ... in the fundamental stages" and "technical and professional education". In the wake of the devastation and dehumanisation wrought by the Second World War, debates on social and economic rights, including the right to education, in the United Nations and UNESCO focused on the idea of human dignity, personal fulfilment and the role of education for international understanding and peace (Elfert 2018, chapter 3). Adult education, in particular, was strongly linked to democracy.

One of the aims of adult education, as formulated at the First International Conference on Adult Education (CONFINTEA I) convened by UNESCO in 1949, was "to foster the true spirit of democracy and the true spirit of humanity" (UNESCO 1949a). In the following decades, the right to education was further defined in a series of international human rights treaties, such as the International Covenant on Economic, Social and Cultural Rights of 1966 (UN 1976, article 13; it entered into force in 1976). UNESCO has played an instrumental role in expanding the right to education to include adults and in promoting a humanistic and emancipatory approach to adult education (Elfert 2015a, 2018), for example through the Nairobi Recommendation on the Development of Adult Learning and Education of 1976 (UNESCO 1976) - renewed in 2015 as the Recommendation on Adult Learning and Education (UNESCO 2015a), the series of International Conferences on Adult Education (CONFINTEA), held every 12-13 years since 1949, and through its pioneering work on the conceptualisation of lifelong learning. UNESCO's vision of lifelong learning as a guiding principle of a democratic learning society is infused by a humanistic philosophy. 
As I have argued elsewhere (Elfert 2015a, 2018), the egalitarian and democratic spirit inherent in the idea of education as a human right reached its fullest expression in UNESCO's work on the concept of lifelong learning, represented by two publications, namely Learning to be (often referred to as the Faure Report) (Faure et al. 1972) and Learning: The Treasure Within (also known as the Delors Report) (Delors et al. 1996). The Faure Report was influenced by the thinking of popular and critical adult educators, such as Paulo Freire, author of Pedagogy of the Oppressed (Freire 1970), for whom the ultimate aim of adult education was liberation and "conscientization" of the working class (Finger and Asún 2001).

However, UNESCO's utopian and citizenship-oriented vision of lifelong learning has largely been supplanted by more economics-driven proposals for education put forward by other international organisations (Rubenson 2006). Although the World Bank and the Organisation for Economic Co-operation and Development (OECD) have promoted adult education periodically, these organisations are guided by a human capital approach to education and do not fully endorse education as a human right. Since the 1980s, under the influence of neoliberalism, many social and economic rights have been rolled back (MacNaughton and Frey 2018). The drive to privatise and commodify education has largely reduced ALE to the acquisition of skills for the job market (Allais 2012; Bowl 2017). In many countries, ALE policy is limited to skills development strategies (DoHET 2015; Elfert and Rubenson 2013). Although lifelong learning remains ubiquitous in policy discourse, in particular in the Western world, its meaning has been adapted to the dominant neoliberal ideology. In most contemporary education policies, adult learning and education are essentially regarded as the responsibility of the individual to acquire (Bagnall 2000).

\section{Conflicting agendas and pressures on adult education and lifelong learning: a short historical review}

Ever since UNESCO was founded in 1945, the organisation has made adult education a priority. In the immediate aftermath of World War II, there were many children and adults who had missed out on years of schooling and education. The reconstruction of societies and the ensuing economic boom called for the fast reintegration of war survivors into the economy. But adult education was also seen as vital to building new democratic societies after the devastating experience of totalitarianism. UNESCO regarded adult education as a necessary instrument to "re-educate" the youth that had been indoctrinated by totalitarian governments (UNESCO 1947, p. 6); it also responded to the spirit of renewal felt by the survivors of the war. In UNESCO's early days, the citizenship dimension of adult education prevailed over the economic dimension, which became more influential from the 1960s onwards. Adult education, and education in general, represented a notion of unity, and adult educators often invoked the concept of "solidarity" (UNESCO 1949a) and "brotherhood" (Jessup 1953).

In 1949, when UNESCO convened CONFINTEA I in Elsinore, Denmark, Director-General Jaime Torres Bodet opened the conference by declaring adult education to be "one of the most important questions of our day and one likely to 
have the most far-reaching consequences" (UNESCO 1949b, p. 7). The delegates endorsed the Universal Declaration of Human Rights (UNESCO 1949a, p. 30), and defined adult education as

more than anything a spiritual condition, a thirst for knowledge, a desire for mental and social freedom, an urge to participate in cultural development (UNESCO 1949b, p. 7).

Johannes Novrup, the Chairperson of CONFINTEA I, viewed adult education as a "radical, almost revolutionary educational idea" (quoted in Jessup 1953, p. 17).

UNESCO's first educational flagship programme, termed Fundamental education, while also encompassing schooling for children, reflected the organisation's strong interest in adult and community-based education. Literacy campaigns constituted an integral component of fundamental education (UNESCO 1949c, pp. 33-37). In the second half of the 1950s, fundamental education came under attack by some Member States who criticised it as colonial and called for greater attention to the development of school systems in developing countries. This criticism was certainly justified. UNESCO's first Director-General Julian Huxley and others perceived fundamental education as a sort of imperialist crusade against ignorance, in which Western education would bring a scientific worldview to those who lived in "darkness" (Huxley 1946 p. 17). However, the colonial nature of the programme was not the only reason for its demise. Adult education became a contested strategy as new actors with new priorities emerged in the system of global education governance.

In the context of decolonisation and the Cold War, when education emerged as a key pillar of international development, the fundamental education programme got entangled in power struggles between UNESCO and other United Nations (UN) bodies (Jones 1988, pp. 90-92). Increasing pressure to focus UNESCO's work on formal education constituted another challenge to the fundamental education programme. The report of a meeting of UNESCO's Fundamental education staff to discuss these challenges addressed the "competition ... between fundamental education and the formal education system" (UNESCO 1956, p. 6). The report states:

In one camp are those who contend that there is no substitute for a system of universal and compulsory primary schooling as a means of achieving widespread literacy ... In the other camp are those whose purpose it is to raise the living standards of the present generation ... and who believe that the adult population must be mobilized (ibid.).

This passage reveals the tension between the advocates of formal education and those who wanted to see a stronger role for adult and non-formal education. The demise of the Fundamental education programme marked the emergence of the "literacy versus schools" dichotomy which runs like a thread through the history of UNESCO and education for development.

In this regard, it is important to take a closer look at what happened to literacy, which represented a major pillar of adult education at the time. In the 1960s, many newly independent Asian and African countries, which used UNESCO 
and the United Nations as platforms for their political claims, advocated for literacy campaigns. From the beginning, UNESCO had pursued a universal literacy campaign, which René Maheu, UNESCO's Director-General from 1962-1974, considered worthy of the Nobel peace prize (Jones and Coleman 2005, p. 202). A proposal for the realisation of such a campaign to the UN General Assembly came to nothing, to a large extent due to the United States' resistance and preference to focus on the expansion of formal school education and technical education. Maheu had no choice but mobilise support for a "kind of consolation measure" (Jones 1988, p. 142), the Experimental World Literacy Programme (EWLP), based on a "functional literacy" approach.

Arthur Gillette maintained that literacy campaigns were not pursued because of the "then-ascendant influence of education-qua-investment economists, for whom literacy work should be focused selectively on the actual or potential producers of a given society" (Gillette 1987, p. 200). UNESCO's literacy approach had fallen into discredit among the funders of EWLP, in particular the World Bank and the United Nations Development Programme (UNDP), as expressed in an April 1968 memorandum by Duncan Ballantine, the World Bank's education director, in which he described the Bank's approach to literacy as "instrumental rather than as an end objective, which it is still to a large extent in the Unesco approach" (quoted in Jones 1992, p. 97; see also Dorn and Ghodsee 2012, p. 375). What Ballantine meant was that UNESCO, in line with its human rights approach to education, pursued a literacy strategy that involved raising the literacy levels of the entire population, including marginalised groups, whereas the World Bank focused on raising only the literacy levels of those parts of the population it considered "instrumental" for economic development. When it was time to evaluate the EWLP, the UNDP and the World Bank considered its results disappointing as, in their view, the programme could not demonstrate a link between rising literacy levels and economic growth (Jones 1992, pp. 98-99).

Charles Dorn and Kristen Ghodsee ascribe the demise of the fundamental education programme and universal literacy to the politicisation of literacy in the context of the Cold War. A United States report on UNESCO identified the goals of fundamental education as "contrary to American ideals and traditions" (Dorn and Ghodsee 2012, p. 375). UNESCO also lost influence as the lead agency of the United Nations system with responsibility for education because it was suspected by some of being sympathetic to communism:

Because of its emphasis on promoting a capitalist path to economic development, the [World] Bank ... agreed to extend loans to educational endeavors as long as these endeavors could be shown to support the promotion of free markets. Because literacy had become ideologically linked with political rather than economic goals, it fell outside of the bank's self-defined agenda to promote redistribution with growth (Dorn and Ghodsee 2012, p. 398).

It was in this context that the United States Agency for International Development (USAID) withdrew its funding to literacy programmes as part of President Kennedy's "Alliance for Progress" initiative in Brazil in 1964, around the same time that René Maheu was forced to abandon the idea of a universal literacy campaign. When, 
in the state of Rio Grande do Norte, a group of workers who had participated in Paulo Freire's literacy programme went on strike, an article in the daily newspaper Jornal do Brasil warned of the liberation of social forces that would be difficult to control (Kirkendall 2010, p. 41).

Literacy's fall from favour was part of a global shift in the approach to adult education for development in the 1960s and 1970s, in which a rationalistic-technocratic and economistic approach to education was dominant. A new group of educational planners and experts "thought of planning as a technical professional activity divorced from politics" (Benveniste 2007, p. 7). It is no surprise that UNESCO's work to promote the concept of lifelong learning (in the 1960s and 1970s, the common concept used was "lifelong education") and its rather high-flown idealistic report on lifelong education, Learning to be (the Faure Report), published in 1972, largely fell on deaf ears in developing countries (Elfert 2018, chapter 5). The newly emerging organisations in the field of education for development saw adult education more as an investment in a market-oriented capitalist economy than as a way to help human beings develop their potential and become active citizens of a democratic society, let alone to transform society as advocated by Paulo Freire and the Faure Report.

UNESCO's humanistic vision of ALE and lifelong learning experienced something of a revival in the years following the collapse of the Soviet Union. Several events, including the International Literacy Year in 1990, the launch of UNESCO's report Learning: A Treasure Within (the Delors Report) in 1996, and a series of optimistic international summits such as CONFINTEA V in 1997 built momentum for a human rights-based approach to education. However, this reversal of fortune was short-lived. The Education for All (EFA) initiative, launched by all major UN organisations at the World Conference on Education for All in Jomtien in 1990, prioritised the expansion of school education. This became particularly apparent at the follow-up conference, the World Education Forum in Dakar in 2000, where lifelong learning all but disappeared from the agenda (Torres 2001). The notion of "basic education", which had been prominent in Jomtien a decade earlier, was effectively interpreted as universal primary education (Power 2015, p. 48).

Following the publication of the Delors Report in 1996, UNESCO greatly reduced its conceptual engagement with lifelong learning. While its specialised institute, the UNESCO Institute for Lifelong Learning, ${ }^{1}$ continued to promote lifelong learning policies, Rethinking Education: Towards a Global Common Good (UNESCO 2015b), the first substantial conceptual report on education published by UNESCO since the Delors Report, did not focus on lifelong learning (Elfert 2015b). However, now that the concept of lifelong learning features prominently in the SDGs, UNESCO is intensifying its conceptual, advocacy and policy-related work on lifelong learning (UIL 2018a, b). It is thus timely to explore the role of adult learning and education (ALE) in the SDGs, in particular from a human rights perspective.

\footnotetext{
${ }^{1}$ Established in 1952 in Hamburg, Germany as the UNESCO Institute for Education (UIE), it became the UNESCO Institute for Lifelong Learning (UIL) in 2006/2007. For a short history of the institute, see Elfert (2013).
} 


\section{Adult education in the context of the Sustainable Development Goals}

What does the emergence of lifelong learning in SDG 4 mean for ALE? We will likely see international organisations, NGOs and civil society revitalising their engagement in activities to conceptualise and promote lifelong learning as a framework for educational reform in developing countries. However, since lifelong learning is a broad concept that encompasses education "from cradle to grave", it remains to be seen whether this will include informal and non-formal education for adults. The monitoring of SDG 4 will take time and involves a myriad of bodies and mechanisms. SDG 4 on education will be reviewed for the first time in July 2019 by the High-Level Political Forum, a key mechanism for monitoring progress of SDG 4 (UN n.d.; UNESCO 2018a).

Opinions on the role of ALE within the SDG framework are merely speculative at this point, illustrated by the fact that two reports, both coming out of UNESCO, reflect divergent interpretations: The 3rd Global Report on Adult Learning and Education (GRALE) emphasises that the SDGs place a stronger focus on adult learning and education than did the MDGs (UIL 2016, p. 15), while UNESCO's Global Education Monitoring Report 2016 observes that "the 10 targets [of SDG 4] fail to deal explicitly with adult education" (UNESCO 2016, p. 222; see also p. 236). In what follows, I will argue that we are unlikely to see a major shift in attention to ALE. I single out three aspects that have been highlighted in recent literature on education for development: (1) the focus on children and schools in international development initiatives and the renewed focus on secondary and higher education in SDG 4 and the global Education 2030 agenda; (2) the lack of funding for adult education; and (3) the lack of attention paid to marginalised groups.

\section{The focus on children and schools in international development initiatives and the renewed focus on secondary and higher education in SDG 4 and the global Education 2030 agenda}

Recent literature suggests that too little attention has been paid to non-formal and informal education relative to formal education in recent decades (Burnett 2017; Fredriksen 2017). Birger Fredriksen (2017) points to a "massive failure in basic skills development" in sub-Saharan Africa, where far greater attention must be given to training in the informal job sector, where most people work. However, most recent development initiatives and bodies have focused on formal education, in particular on schooling for children, such as the Global Partnership for Education, ${ }^{2}$ the United Nations' Global Education First initiative ${ }^{3}$ and The Learning Generation report prepared by the International Commission on Financing Global Education Opportunity (Education Commission 2016), which calls for greater attention to secondary and

\footnotetext{
${ }^{2}$ The Global Partnership for Education (GPE), which grew out of the World Bank's Education for All Fast-Track initiative (FTI), is a multi-stakeholder partnership that raises funds for education and allocates them to low-income countries.

3 The United Nations' Global Education First initiative (GEFI) was launched in 2012 as a five-year initiative "for the final push" (GEFI website; http://www.globaleducationfirst.org/308.htm [accessed 27 May 2019]) towards the achievement of the second MDG, universal primary education.
} 
pre-primary education. The report refers to ALE only in terms of vocational training, leading Steven Klees to criticise the report's "complete disregard for adult education ... and the only cursory attention to education as a human right" (Klees 2017, p. 438). The consensus on the expansion of primary education already built up in the post-war years reached its peak during the 1980s and 1990s when the World Bank was influenced by studies showing that investment in primary education yielded the highest rates of return. In a recent report, George Psacharopoulos, who authored many of those World Bank studies, continues to designate increases in pre-school and primary education enrolment, as well as the improvement of school quality, as the "targets with the highest cost-benefit ratios" (Psacharopoulos 2014, p. I).

On the other hand, recent OECD studies indicate that rates of return are higher for tertiary than for primary education (cited in Bray and Varghese 2011, p. 27). Several commentators such as Karen Mundy and Antoni Verger suggest that the financial crisis of 2008 has shifted the focus of international investment towards secondary and tertiary education:

The financial crisis secured a trend that tilts Bank education lending towards large emerging economies, and away from basic education to secondary and tertiary levels of education, which are in particular demand among emerging market economies (Mundy and Verger 2015, p. 16).

Several studies have pointed to the renewed focus on higher education in SDG 4 (UNESCO-IIEP 2017; Owens 2017), which will not help to increase the profile of adult education. As the Global Education Monitoring Report 2016 declared the SDG 4 secondary education goals to be "unattainable" (UNESCO 2016, p. 173, see also Klees 2017, p. 428), Fredriksen's (2016) warning that the excessive focus on secondary and higher education will detract from countries' ability to even meet primary education targets makes a lot of sense.

The neglect of adult literacy is reflected in the fact that the total number of adults with low literacy skills has dropped by just one per cent since 2000 (UNESCO 2014, p. 4). The lack of improvement in adult literacy rates, particularly in sub-Saharan Africa, seems to contradict the perennial argument that universal schooling will ultimately produce a literate population: "Despite the impressive gains in access to primary education between 2000 and 2015, SSA [sub-Saharan Africa]'s adult literacy rate barely improved" (Fredriksen 2016). Massive dropout rates and stagnating literacy rates seem to vindicate those development educationists who point to a strong correlation between adult literacy and school success (ActionAid and Global Campaign for Education 2005, p. 8). However, as I have argued above, general interest in literacy has waned. Although some countries have invested in literacy campaigns in recent years, such as Kha Ri Gude in South Africa (McKay 2015) and Brazil Alfabetizado in Brazil (Hanemann 2015), and the African Union has included literacy campaigns among the strategic objectives of its Continental Education Strategy for 
Africa 2016-2025 (AU 2016), when budgets are tight, countries tend to prioritise investments in children's education (UIL 2017a, p. 19; Ireland 2016, pp. 5-6), and most of the education grants allocated by the Global Partnership for Education fund primary education (GPE 2017). In this regard it is important to note that the 2011 revised version of the International Standard Classification of Education (ISCED) removed the concept of "basic education" from ISCED levels 1 and 2; these are now referred to solely as "primary education" and "lower secondary education" (UIS 2013 , p. 8). This clearly denotes a focus on schooling and reduces the pressure on governments to invest in adult literacy.

\section{The lack of funding for adult education}

The volume of international aid to education is decreasing (UNESCO 2017; UIL 2017 b, p. 19). The financial crisis had a devastating effect on social and economic rights (Nolan 2016) and has greatly impacted donors' investments in education for development. Against this background, the UNESCO Global Education Monitoring Report 2016 states that "adult education remains a low priority in budgets" (UNESCO 2016, p. 239). This low spending on adult education is an indicator of its marginalisation. According to the 2017 CONFINTEA mid-term reports (UIL 2017a, b), the majority of countries spent less than 2 per cent of their national education budget on adult education. Although several countries reported some progress in political commitment to adult education (UIL 2017a, p. 11) and improved stakeholder coordination (ibid., p. 15), a slight increase in spending or the intention to increase spending, "in real terms ... given the severe depreciation of many African currencies, it is more likely to have been a decrease" (UIL 2017a, p. 18, b, p. 6).

The CONFINTEA mid-term review did not express much optimism about the funding situation in South Asia either: "The low level of spending on ALE in some countries in South Asia, with a substantial backlog of illiteracy and a large expanding youth population, is a matter of serious concern" (UIL 2017b, p. 19). A few African countries such as Senegal and Nigeria reported that they had received new funding from international bodies (ibid., p. 6). Others reported on cost-sharing schemes with civil society partners (ibid., p. 6), which point to the sporadic and adhoc nature of funding for adult education, which "in several countries ... continues to be seen as a temporary project and does not find a place in the regular national budget, leaving the sub-sector to depend essentially on extra-budgetary resources from NGOs and development partners" (UIL 2017b, p. 19). The report further cautions: "Increased dependence on funding through fees and private sources may eventually lead to decreased government financing" (ibid.).

The increased reference to the role of the private sector in filling funding gaps is alarming:

The results of the 3rd Conference on Financing for Development held in Addis Ababa, in July 2015, were not encouraging, concluding with the understanding that a large part of the funding will have to be sought in the private sector (Ireland 2016, p. 10). 
UNESCO officials seem disenchanted with the prospects of private funding. In a 2015 article, Jordan Naidoo, currently Director of the Division for Education 2030 Support and Coordination at UNESCO, stated that "international public finance plays an important role in complementing the efforts of countries to mobilize public resources domestically" (Naidoo 2015). In a later article, Naidoo seemed to have lost much of his optimism. Referring to the funding gap for education in developing countries, he wrote: "The role of the private sector, while increasingly in the spotlight, is not clear, both in terms of increased funding but also its impact on the right to education" (Naidoo 2017). Given the massive shift in the political economy towards privatisation of education (Verger et al. 2016) and the way the discourse of lifelong learning has been used to advance a market-oriented agenda of employability (Martin 2003; Elfert 2018, chapter 7), there is a real risk that we will see a privatisation of adult education similar to the current development in relation to schooling (Steiner-Khamsi and Draxler 2018).

\section{The lack of attention paid to marginalised groups}

Although the literacy goal of the previous EFA framework ${ }^{4}$ has not been achieved, UNESCO's old dream of universal literacy has been effectively buried in the formulation of SDG target 4.6 that "a substantial proportion of adults ... achieve literacy and numeracy" (Hanemann 2016; Torres 2017). Looking at data from the EFA period, a 2009 background study carried out by UNESCO on national EFA reports targeting marginalised populations revealed a strong focus on children in national education plans. In relation to EFA Goal 3, to "Promote learning and life skills for young people and adults", the study found that only 30 per cent of the reports mention marginalised groups in relation to secondary education (UNESCO-IIEP 2009, p. 16). Most of the countries focused on achieving gender parity. Very few plans -5 out of 44 - included specific targets for marginalised groups. Four of the plans that included targets focused on girls, and in one case, on poor and vulnerable youth (ibid., p. 17). The report further stated that "few countries propose specific measurable targets for disadvantaged groups" (ibid., p. 36).

Another important finding pointed out by the UNESCO-IIEP study is that "very few plans ... contain an analysis of the situation of marginalized or disadvantaged groups" (UNESCO-IIEP 2009, p. 36). As a consequence, targets and strategies remain at a general level (ibid., p. 37). The study further suggests that "the lack of specific targets may also reflect an unwillingness to commit to specific promises. Committing to strategies is probably easier than committing to targets" (ibid., p. 37). The disconnect between targets and strategies and the lack of analysis found in the reports indicate that countries currently fail to pay close attention to the educational needs of disadvantaged groups.

\footnotetext{
${ }^{4}$ The EFA literacy goal was to achieve "a 50 per cent improvement in levels of adult literacy by 2015 , especially for women, and equitable access to basic and continuing education for all adults" (UNESCO 2015c, p. 137).
} 
Other data confirm these findings. The 3rd Global Report on Adult Learning and Education reported that

the most marginalized, disadvantaged and poorest people are persistently excluded from ALE activities (UIL 2016, p. 14).

The CONFINTEA mid-term report for sub-Saharan Africa points out that neither a human rights perspective on ALE nor a focus on marginalised groups are "particularly prominent" (UIL 2017a, p. 10) in the country responses: "Apart from the belief that literacy provision to adults should be limited to 'functional literacy', formal recognition and equivalency to conventional schooling are the strongest themes" (ibid.). The report further states that the "socially excluded, the disabled, minorities, migrants, refugees and the long-term unemployed" were "relatively neglected" (ibid., p. 11). Against the background of the dramatic struggles of migrants, refugees, indigenous peoples, racialised groups and people living in poverty, and considering the crucial role adult education could play in tackling these challenges, the lack of attention paid to the plight of the most vulnerable, as revealed by these reports, is disturbing but not surprising, given the historical marginalisation of adult education in education for development. As I have shown above, adult education has been overshadowed by formal school education, and where it has been supported, this was mainly as a strategy for promoting economic growth.

\section{Concluding remarks: the lack of a transformative vision}

In this section I come back to my initial question: In the context of the SDGs, will the human rights-based approach to adult education see a revival after a long period of investment in primary education? I believe there is reason for scepticism, given the lack of a political and transformative vision in the SDGs, despite the title of the 2030 Agenda for Sustainable Development, "Transforming our world" (UN 2015). The SDGs are embedded in an overall climate that depoliticises social problems. As Valeria Esquivel observed, "Agenda 2030 aims at 'transforming our world', but intends to get there without substantially opposing the powers that be. Power relations are the big elephant in the room of Agenda 2030" (Esquivel 2016, p. 12).

Scholars looking at EFA had already observed a tendency in international development frameworks and activities to propose strategies and elaborate accountability mechanisms as solutions for identified problems without discussing the underlying reasons for these problems. Karen Mundy suggested that EFA stood for "a global consensus that actively avoids an understanding of development focused on global structural inequalities" (Mundy 2007, p. 25). In his analysis of the discourse of the Dakar Framework for Action (WEF 2000), the outcome document of the World Education Forum in Dakar in 2000 and the precursor of the Incheon Declaration (WEF 2015), Laurence Tamatea (2005) revealed the "matrix-like effects" of the Dakar Framework for Action. He argued that, while employing a humanistic rhetoric, the Framework put forward common-sense discourse, such as the imperatives of "quality," "transparency" and "accountability" that contribute to the "McDonald'slike homogenizing of global education" (Tamatea 2005, p. 313) and carry forward 
"colonialist and imperial legacies" (ibid., p. 329). According to Klees, "the SDGs will lock in the global development agenda for the next fifteen years around a failing economic model that requires urgent and deep structural changes" (Klees 2017, p. 436, citing Hickel 2015).

In a similar vein, several scholars and civil society representatives have criticised the SDGs for buttressing the status quo (Smith 2018), adhering to a neoliberal framework (Struckmann 2018), and failing to address "structural power relations" (Esquivel 2016). Jeffrey Smith (2018) points to the glaring absence of the word "democracy" in the 17 SDGs. Lynette Shultz (2015, p. 101) had already observed the disappearance of references to democracy in UNESCO documents a few years back. In this vein, Timothy Ireland recently pointed out that

the underlying logic of both the Education 2030 Framework and Transforming our World: The 2030 Agenda for Sustainable Development is Eurocentric and Western liberal and neoliberal. These agendas, although promising to reduce world poverty, will do little to question or transform the existing relations of power and structures of oppression which contribute to unequal opportunities for development (Ireland 2018, p. 24).

Given the historical discreditation of adult education as too political, the depoliticisation of social problems will likely not play out in favour of the human rightsbased approach to ALE. Informal and non-formal learning are associated with social movements, grassroots community-organising and collective activity that have been largely dismissed in favour of an approach in which learning is constructed as an individual and personal issue. The SDGs fail to address the underlying structural issues such as poverty reduction that need to be tackled in order to achieve the goals. As Gillian MacNaughton (2018) has argued in relation to SDG 10, although the goal addresses economic inequalities, it focuses on the bottom 40 per cent instead of the gap between the bottom 40 per cent and the top 10 per cent or 1 per cent.

Without a transformative vision, the reference to human rights in the SDGs is little more than a token to make it more acceptable to civil society. While the rhetoric of the global education agendas invokes the discourse of human rights, citizenship and social inclusion, "policies often prioritize economic objectives, placing more emphasis on formal ALE and labour market outcomes than on non-formal ALE, which tends to have less tangible community outcomes" (UIL 2016, p. 14). Just like the Dakar Framework, the new international education targets and strategies stay within the "matrix"; they are meant to reproduce society as it is rather than present a vision that transcends it.

Civil society has traditionally tended to advocate a human rights approach to ALE, but it is not clear what the influence of civil society is on the policy direction of ALE. In Latin America, for example, the popular education movement differs profoundly from what most national governments propose as policy for adult education (personal communication with Timothy Ireland, 6 February 2018). Although the consultation process leading up to the SDGs has involved civil society organisations and was more transparent and inclusive than the MDG process (Fukuda-Parr and McNeill 2019), Bhumika Muchhala, Ranja Sengupta and Chee Yoke Ling have criticised last-minute changes to the text "behind closed doors" (Muchhala et al. 
2015, para 7) in meetings attended only by Member States' representatives. These "back-room discussions were a stark contrast to the integrity of the process in which the SDGs were formulated" (ibid., para 10).

Another question is how informal and non-formal learning can be monitored and measured. As the Global Education Monitoring Report 2019 observes, "lifelong learning opportunities represent half of the SDG 4 formulation but receive only a fraction of global attention" (UNESCO 2018b, p. 266). Aaron Benavot and Ashley Stepanek Lockhart point to the lack of available data for participation in nonformal education in developing countries (Benavot and Stepanek Lockhart 2016, p. 5). They further maintain that the "skills" agenda might make it difficult to monitor progress in adult education, as the lack of a common definition of "relevant skills" for some of the targets in SDG 4 could undermine their monitoring (ibid., pp. 4-5; see also King 2017, p. 807). Furthermore, there is considerable disparity between the ambitious goals and the narrow indicators used to measure them (Unterhalter 2019; see also King 2017). An example in relation to adult education is SDG target 4.4, which reads: "By 2030, substantially increase the number of youth and adults who have relevant skills, including technical and vocational skills, for employment, decent jobs and entrepreneurship". The respective indicator 4.4.1 only refers to the "proportion of youth and adults with information and communications technology (ICT) skills, by type of skill", clearly narrowing "relevant skills" to technological skills.

When asked why lifelong learning was included in SDG 4, a former UNESCO staff member responded, because "it doesn't cost anything" and "it doesn't hurt anyone" (personal communication). In a recent UNESCO paper, another former UNESCO staffer, Carlos Vargas, referring to Colin Griffin (2000), argued along the same lines: "Lifelong learning apparently advantages everyone and disadvantages no-one" (Vargas 2017, p. 5). At the time of EFA, "the Third World countries regarded lifelong education as a luxury of the Developed World" (Rubenson 2006, p. 71). Today the discourse of lifelong learning is globally accepted and has become "the preferred formula for preparing individuals and societies for a life of uncertainty and insecurity, unstable jobs and changing work profiles and locations" (Vargas 2017, p. 6; see also Elfert 2018, chapter 7). The citizenship dimension of adult education in the post-World War II years, with its emphasis on emancipation, solidarity and democracy, has largely disappeared. At the same time, the role of UNESCO in the system of global governance has diminished. UNESCO was created as the lead agency of the UN system for education, but since the 1960s it has lost much of its influence to other international organisations, such as the World Bank (Elfert 2017). Its humanistic approach lost out to the human capital approach, which is more congruent with a market-driven economic system. As Timothy Ireland has shown, there is no evidence that any progress has been achieved in the advancement of a human rights-driven agenda for adult education between CONFINTEA $\mathrm{V}$ in 1997 and CONFINTEA VI in 2009 (Ireland 2016).

The historical analysis I have offered in this article provides a clearer picture of the role and position of ALE, especially from a human rights perspective, within the development education agenda. Although the SDGs contain clear opportunities for lifelong learning, there is little to indicate that the human rights-oriented tradition 
of adult education with its focus on democratic agency and collective action will re-emerge within the confines of the "matrix". As Klees rightly states, referring to the late UN Special Rapporteur on the Right to Education, Katarina Tomasevski, "if education were truly a human right, we would not be waiting until 2030 or 2040 to ensure it" (Klees 2017, p. 438, referring to Tomasevski 2003). I would like to add, if education were truly a human right, it would include all people, especially the poorest and most marginalised. The right to education means education for all.

However, given the enormity of global problems facing the international community, including climate change and the growing precarity of employment, there is hope that the re-emergence of lifelong learning may lead to educational reforms that will improve people's lives. There is hope that policymakers will develop greater awareness of the need to think outside of the "matrix" in order to effectively tackle global problems. The human rights-based approach to adult education certainly would have much to contribute to "transforming our world".

Open Access This article is distributed under the terms of the Creative Commons Attribution 4.0 International License (http://creativecommons.org/licenses/by/4.0/), which permits unrestricted use, distribution, and reproduction in any medium, provided you give appropriate credit to the original author(s) and the source, provide a link to the Creative Commons license, and indicate if changes were made.

\section{References}

ActionAid \& Global Campaign for Education. (2005). Writing the wrongs: International benchmarks on adult literacy. London: ActionAid International. Retrieved 24 April 2019 from https://www. right-to-education.org/sites/right-to-education.org/files/resource-attachments/Archer_Writing_the_ Wrongs_2005_En.pdf.

Allais, S. (2012). Will skills save us? Rethinking the relationships between vocational education, skills development policies, and social policy in South Africa. International Journal of Educational Development, 32(5), 632-642.

AU (African Union). (2016). Continental education strategy for Africa 2016-2015. Addis Ababa: African Union Headquarters. Retrieved 5 August 2018 from https://au.int/sites/default/files/docum ents/29958-doc-cesa_-_english-v9.pdf.

Bagnall, R. G. (2000). Lifelong learning and the limitations of economic determinism. International Journal of Lifelong Education, 19(1), 20-35.

Benavot, A. (2018). The invisible friend: Adult education and the Sustainable Development Goals. Adult Education and Development, 58 [Role and impact of adult education], 4-9.

Benavot, A., \& Stepanek Lockhart, A. (2016). Monitoring the education of youth and adults: From EFA to SDG 4. In H. Hinzen \& S. Schmitt (Eds), Agenda 2030 - Education and Lifelong Learning in the Sustainable Development Goals. International Perspectives in Adult Education, 75 (pp. 55-63). Bonn: DVV International.

Benveniste, G. (2007). Creation of the International Institute for Educational Planning. Educational Planning, 16(3), 1-9.

Bowl, M. (2017). Adult education in neoliberal times: Policies, philosophies and professionalism. London: Palgrave Macmillan.

Bray, M., \& Varghese, M. V. (Eds.). (2011). Directions in educational planning. International experiences and perspectives. Paris: International Institute for Educational Planning (IIEP).

Burnett, N. (2017). Unfinished business in global education. NORRAG NewsBite [blogpost, 13 March 2017]. Retrieved 24 April 2019 from http://www.norrag.org/unfinished-business-in-global-educa tion/. 
Delors, J., et al. (1996) Learning: The treasure within. Report to UNESCO of the International Commission on Education for the Twenty-first century. Paris: UNESCO.

DoHET (Department of Higher Education and Training, Republic of South Africa). (2015). National Skills Development Strategy (NSDS III). Pretoria: Department of Higher Education and Training.

Dorn, C., \& Ghodsee, K. (2012). The Cold War politicization of literacy: Communism, UNESCO and the World Bank. Diplomatic History, 36(2), 373-398.

Education Commission. (2016). The learning generation: Investing in education for a changing world. New York, NY: International Commission on Financing Global Education Opportunity (the Education Commission). Retrieved 31 July 2018 from http://report.educationcommission.org/wp-conte nt/uploads/2016/09/Learning_Generation_Full_Report.pdf.

Elfert, M. (2013). Six decades of educational multilateralism in a globalising world: The history of the UNESCO Institute in Hamburg. International Review of Education, 59(2), 263-287.

Elfert, M. (2015a). UNESCO, the Faure report, the Delors report, and the political utopia of lifelong learning. European Journal of Education, 50(1), 88-100.

Elfert, M. (2015b). Rethinking education: Towards a global common good? UNESCO's new humanistic manifesto? NORRAG NewsBite. [blogpost, 23 December 2015]. Retrieved 24 April 2019 from https://www.norrag.org/rethinking-education-towards-a-global-common-good-unescos-newhumanistic-manifesto/.

Elfert, M. (2017). UNESCO, the World Bank, and the struggle over education for international development through the lens of the Faure report and Delors report. L'éducation en débats: Analyse comparée, $8,5-21$.

Elfert, M. (2018). UNESCO's utopia of lifelong learning: An intellectual history. Routledge research in lifelong learning and adult education series. New York: Routledge.

Elfert, M., \& Rubenson, K. (2013). Adult education policies in Canada: Skills without humanity. In T. Nesbit, N. Taber, S. Brigham, \& T. Gibb (Eds.), Building on critical traditions: Adult education and learning in Canada (pp. 238-248). Toronto: Thompson Educational Publishing.

Esquivel, V. (2016). Power and the Sustainable Development Goals: A feminist analysis. Gender \& Development, 24(1), 9-23.

Faure, E., Herrera, F., Kaddoura, A. R., Lopes, H., Petrovsky, A. V., Rahnema, M. \& Ward, F. C. (1972). Learning to be: The world of education today and tomorrow. Paris: UNESCO/Harrap. Retrieved 24 April 2019 from https://unesdoc.unesco.org/ark:/48223/pf0000001801.

Finger, M., \& Asún, J. M. (2001). Adult education at the crossroads. Learning our way out. London: Zed Books.

Fredriksen, B. (2016). Might the ambitious targets for post-basic education further delay achievement of universal basic education beyond 2030 in sub-Saharan Africa? NORRAG NewsBite [blogpost, 15 December 2016]. Retrieved 23 April 2019 from https://www.norrag.org/might-the-ambitious-targe ts-for-post-basic-education-further-delay-achievement-of-universal-basic-education-beyond-2030in-sub-saharan-africa/.

Fredriksen, B. (2017). Creating productive jobs for Africa's youth: A huge challenge with global implications. NORRAG NewsBite [blogpost, 8 June 2017]. Retrieved 23 April 2019 from https://www. norrag.org/creating-productive-jobs-africas-youth-huge-challenge-global-implications/.

Freire, P. (1970). Pedagogy of the oppressed. New York: Continuum.

Fukuda-Parr, S., \& McNeill, D. (2019). Knowledge and politics in setting and measuring the SDGs: Introduction to special issue. Global Policy, 10(1), 5-15.

Gillette, A. (1987). The Experimental World Literacy Program. A unique international effort revisited. In R. F. Arnove \& H. J. Graff (Eds.), National literacy campaigns: Historical and comparative perspectives (pp. 197-219). New York: Plenum Press.

GPE (Global Partnership for Education). (2017). Portfolio review 2017. Washington, DC: Global Partnership for Education.

Griffin, C. M. (2000). Lifelong learning and welfare reform. International Journal of Lifelong Education, $18(6), 431-452$.

Hanemann, U. (2015). The evolution and impact of literacy campaigns and programmes 2000-2014. UIL Research Series, no. 1. Hamburg: UNESCO Institute for Lifelong Learning. Retrieved 24 April 2019 from https://unesdoc.unesco.org/ark:/48223/pf0000234154.

Hanemann, U. (2016). Fulfilling the right to literacy and numeracy as part of basic education for all. NORRAG News, 54 [Education, training and agenda 2030: What progress one year on?], 110-111. Retrieved 24 April 2019 from http://www.norrag.org/fileadmin/Full\%20Versions/NN54.pdf. 
Hickel, J. (2015). The problem with saving the world: The UN's new Sustainable Development Goals aim to save the world without transforming it. Jacobin [blogpost 8 August 2015]. Retrieved 25 April 2019 from https://www.jacobinmag.com/2015/08/global-poverty-climate-change-sdgs/.

Huxley, J. (1946). UNESCO: Its purpose and its philosophy. Paris: UNESCO Preparatory Commission.

Ireland, T. (2016). Reflections on CONFINTEA and the global agendas for education and development post-2015. Voices Rising no. 497. [ICAE electronic bulletin, 24 October 2016]. Toronto: International Council for Adult Education (ICAE).

Ireland, T. (2018). The relevance of Freire for the post-2015 international debate on development and education and the role of popular education. In A. Melling \& R. Pilkington (Eds.), Paulo Freire and transformative education: Changing lives and transforming communities (pp. 15-27). London: Palgrave Macmillan.

Jessup, F. W. (Ed.) (1953). Adult education towards social and political responsibility. International conference held from the 8th to the 13th September, 1952. Hamburg: UNESCO Institute for Education. Retrieved 24 April 2019 from https://unesdoc.unesco.org/ark:/48223/pf0000131344?posIn Set=1\&queryId=c8093586-ea8f-469f-b367-b83335801bc2.

Jones, P. W. (1988). International policies for Third World education: UNESCO, literacy and development. London: Routledge.

Jones, P. W. (1992). World Bank financing of education: Lending, learning and development. London: Routledge.

Jones, P. W., \& Coleman, D. (2005). The United Nations and education: Multilateralism, development and globalisation. London: RoutledgeFalmer.

King, K. (2017). Lost in translation? The challenge of translating the global education goal and targets into global indicators. Compare: A Journal of Comparative and International Education, 47(6), 801-817.

Kirkendall, A. J. (2010). Paulo Freire \& the Cold War politics of literacy. Chapel Hill: The University of North Carolina Press.

Klees, S. (2017). Will we achieve education for all and the education for sustainable development goal? Comparative Education Review, 61(2), 425-440.

MacNaughton, G. (2018). Equality rights beyond neoliberal constraints. In G. MacNaughton \& D. Frey (Eds.), Economic and social rights in a neoliberal world (pp. 103-124). Cambridge: Cambridge University Press.

MacNaughton, G., \& Frey, D. F. (Eds.). (2018). Economic and social rights in a neoliberal world. Cambridge: Cambridge University Press.

Martin, I. (2003). Adult education, lifelong learning and citizenship: Some ifs and buts. International Journal of Lifelong Education, 22(6), 566-579.

McGrath, S. (2018). Education and development. Routledge perspectives on development. London: Routledge.

McKay, V. (2015). Measuring and monitoring in the South African Kha Ri Gude mass literacy campaign. International Review of Education, 61(3), 365-397.

Morsink, J. (2000). The universal declaration of human rights: Origins, drafting, and intent. Pennsylvania studies in human rights series. Philadelphia, PA: University of Pennsylvania Press.

Muchhala, B., Sengupta, R., \& Ling, C. Y. (2015). UN post-2015 development agenda adopted amidst closed-door deals. Social Watch [online article, 15 August]. Retrieved 31 July 2018 from http:// www.socialwatch.org/node/17008.

Mundy, K. (2007). Education for All: Paradoxes and prospects of a global promise. In D. Baker \& A. W. Wiseman (Eds.), Education for All: Global promises, national challenges. International Perspectives on Education and Society series (vol. 8, pp. 1-30). Bingley: Emerald Group Publishing.

Mundy, K., \& Verger, A. (2015). The World Bank and the global governance of education in a changing world order. International Journal of Educational Development, 40, 9-18.

Naidoo, J. (2015). UNESCO committed to leading coordination of new education agenda. Global Education Monitoring Report. World Education Blog [blogpost 7 September 2015]. Paris: UNESCO Global Education Monitoring Report team. Retrieved 23 April 2019 from https://gemreportunesco .wordpress.com/2015/09/07/unesco-committed-to-leading-coordination-of-new-education-agenda/.

Naidoo, J. (2017). Agenda 2030 - SDG 4 Education 2030-One year on: Challenges and opportunities. NORRAG NewsBite [blogpost 24 January 2017]. Retrieved 23 April 2019 from https://www.norra g.org/agenda-2030-sdg4-education-2030-one-year-on-challenges-and-opportunities/.

Nolan, A. (Ed.). (2016). Economic and social rights after the global financial crisis. Cambridge: Cambridge University Press. 
Owens, T. L. (2017). Higher education in the sustainable development goals framework. European Journal of Education, 52(4), 414-420.

Power, C. (2015). The power of education: Education for All, development, globalisation and UNESCO. Dordrecht: Springer.

Psacharopoulos, G. (2014). Benefits and costs of the education targets for the post-2015 development agenda. Education Assessment Paper series. Copenhagen: Copenhagen Consensus Center. Retrieved 31 July 2018 from http://www.copenhagenconsensus.com/sites/default/files/education_ assessment_-_psacharopoulos_0.pdf.

Rubenson, K. (2006). Constructing the lifelong learning paradigm: Competing visions from the OECD and UNESCO. In S. Ellers (Ed.), Milestones in adult education (pp. 63-78). Copenhagen: Danish University Press.

Shultz, L. (2015). Decolonizing UNESCO's post 2015 education agenda: Global social justice and a view from UNDRIP. Postcolonial Directions in Education, 4(2), 96-115.

Smith, J. (2018). How the UN Development Goals undermine democracy. Quartz Africa [online news, posted 7 June 2018]. Retrieved 31 July 2018 from https://qz.com/1299149/how-the-uns-sustainabl e-development-goals-undermine-democracy/.

Steiner-Khamsi, G., \& Draxler, A. (2018). The state, business and education. Public-private partnerships revisited. NORRAG Series on International Education and Development. Cheltenham, UK and Northhampton, MA: Edward Elgar Publishing.

Struckmann, C. (2018). A postcolonial feminist critique of the 2030 Agenda for Sustainable Development: A South African application. Agenda. Empowering Women for Gender Equity, 32(1), 12-24.

Tamatea, L. (2005). The Dakar framework: Constructing and deconstructing the global neoliberal matrix. Globalisation, Societies and Education, 3(3), 311-334.

Tomasevski, K. (2003). Education denied: Costs and remedies. London: Zed Books.

Torres, R. M. (2001). What happened at the World Education Forum? Adult Education and Development, $56,45-68$.

Torres, R. M. (2002). Lifelong learning in the North, Education for All in the South. In C. MedelAnoñuevo (Ed.), Integrating lifelong learning perspectives (pp. 3-12). Hamburg: UNESCO Institute for Education. Retrieved 24 April 2019 from https://unesdoc.unesco.org/ark:/48223/pf000 0126485? posInSet=1\&queryId=a1c9f486-b893-4a9f-9b7d-5ef29e75c0e0.

Torres, R.M. (2017). Literacy: From all to "a substantial proportion of adults". OTRAEducation Blog. [blogpost November 2017]. Retrieved 31 July 2018 from http://otra-educacion.blogspot. com/2017/11/literacy-from-all-to-substantial.html.

UIL (UNESCO Institute for Lifelong Learning). (2016). 3rd Global report on adult learning and education (GRALE III). Key messages and executive summary. Hamburg: UIL. Retrieved 31 July 2018 from http://unesdoc.unesco.org/images/0024/002459/245917e.pdf.

UIL. (2017a). The status of adult learning and education in sub-Saharan Africa. CONFINTEA VI midterm review 2017. Regional report. Hamburg: UIL. Retrieved 31 July 2018 from http://unesd oc.unesco.org/images/0025/002597/259720E.pdf.

UIL. (2017b). Progress, challenges and opportunities: The status of adult learning and education. CONFINTEA VI mid-term review 2017. Summary of the regional reports. Hamburg: UIL. Retrieved 31 July 2018 from http://unesdoc.unesco.org/images/0025/002597/259707E.pdf.

UIL. (2018a). Under way: Handbook on lifelong learning [webnews 30 July 2018]. Hamburg: UIL. Retrieved 24 April 2019 from http://uil.unesco.org/lifelong-learning/policies-database/under-wayhandbook-lifelong-learning.

UIL. (2018b). UNESCO holds international consultative meeting to look at the governance of lifelong learning [webnews 18 October 2018]. Hamburg: UIL. Retrieved 24 April 2019 from http://uil. unesco.org/unesco-holds-international-consultative-meeting-look-governance-lifelong-learning.

UIS (UNESCO Institute for Statistics). (2013). Never too late to complete school. Results of the UIS survey on adult education and literacy programmes in Latin America and the Caribbean. UIS Information Paper no. 15. Montreal: UNESCO Institute for Statistics. Retrieved 25 April 2019 from http://uis.unesco.org/sites/default/files/documents/never-too-late-to-complete-school-results-ofthe-uis-survey-on-adult-education-and-literacy-programmes-in-latin-america-and-the-caribbean2014-en_0.pdf.

UN (United Nations). (n.d.). High-level political forum on sustainable development. Department of Economic and Social Affairs [dedicated webpage]. New York: UN. Retrieved 21 April 2019 from https ://sustainabledevelopment.un.org/hlpf. 
UN. (1948). Universal declaration of human rights. Paris: United Nations. Retrieved 25 April 2019 from https://unesdoc.unesco.org/ark:/48223/pf0000074116.nameddest=74129.

UN. (1976). International Covenant on Civil and Political Rights. Adopted and opened for signature, ratification and accession by General Assembly resolution 2200A (XXI) of 16 December 1966, entry into force 23 March 1976, in accordance with Article 49. New York: United Nations. Retrieved 26 April 2019 from https://www.ohchr.org/EN/ProfessionalInterest/Pages/CESCR.aspx.

UN. (2015). Transforming our world: The 2030 Agenda for Sustainable Development. A/RES/70/1. New York: UN. Retrieved 23 April 2019 from https:/www.un.org/ga/search/view_doc.asp?symbol=A/ RES/70/1\&Lang=E.

UNESCO (United Nations Scientific, Educational and Cultural Organization). (1947). Report of the meeting of the UNESCO Committee on the Philosophic Principles of the Rights of Man. Paris, June 26-July 2. Phil./9. Paris: UNESCO. Retrieved 31 July 2018 from http://unesdoc.unesco.org/image s/0012/001243/124347Eb.pdf.

UNESCO. (1949a). Summary report of the International Conference on Adult Education. Elsinore, Denmark 19-25 June 1949. Paris: UNESCO. Retrieved 31 July 2018 from http://unesdoc.unesco.org/ images/0007/000712/071263eo.pdf.

UNESCO. (1949b). UNESCO Courier, II(6) (July).

UNESCO. (1949c). Fundamental education: Description and programme. Monographs on Fundamental Education series, vol. 1. Paris: UNESCO.

UNESCO. (1956). Conference of fundamental education experts. Unesco House, Paris, 18-29 June 1956. Working Paper 2. Description of fundamental education. UNESCO/FE/TA/Conf., WS/066.16. Paris: UNESCO. Retrieved 31 July 2018 from http://unesdoc.unesco.org/images/0014/00145 1/145197eb.pdf.

UNESCO. (1976). Recommendation on the development of adult education. Adopted by the General Conference at its nineteenth session, Nairobi, 26 November 1976. Paris: UNESCO. Retrieved 25 April 2019 from http://www.unesco.org/education/pdf/NAIROB_E.PDF.

UNESCO. (2014). Teaching and learning: Achieving quality for all. EFA Global Monitoring Report. Paris: UNESCO. Retrieved 25 May 2019 from https://unesdoc.unesco.org/ark:/48223/pf00002256 60.

UNESCO. (2015a). Recommendation on adult learning and education. Paris/Hamburg: UNESCO/ UIL. Retrieved 25 April 2019 from https://unesdoc.unesco.org/ark:/48223/pf0000245179?posIn Set=2\&queryId=cb1b4cf1-4e7d-4e83-b91d-4e35be94d518.

UNESCO. (2015b). Rethinking education: Towards a global common good? Paris: UNESCO. Retrieved 4 December 2018 from http://unesdoc.unesco.org/images/0023/002325/232555e.pdf.

UNESCO. (2015c). Education for all 2000-2015: Achievements and challenges. Education for All Global Monitoring Report 2015. Paris: UNESCO. Retrieved 23 May 2019 from https://unesdoc.unesc o.org/ark:/48223/pf0000232205?posInSet=3\&queryId=0982e5de-1a08-49c3-bf68-92d5e7351c40.

UNESCO. (2016). Education for people and planet: Creating sustainable futures for all. Global Monitoring Education Report 2016. Paris: UNESCO. Retrieved 31 July 2018 from http://unesdoc.unesc o.org/images/0024/002457/245752e.pdf.

UNESCO. (2017). Aid to education falls for the sixth consecutive year [webnews 6 June 2017]. Paris: UNESCO. Retrieved 31 July 2018 from http://en.unesco.org/news/aid-education-falls-sixth-conse cutive-year.

UNESCO. (2018 [1945]). Constitution of the United Nations Educational, Scientific and Cultural Organization. In UNESCO, Basic texts: 2018 edition (pp. 5-18). Paris: UNESCO. Retrieved 23 May 2019 from https://unesdoc.unesco.org/ark:/48223/pf0000261751.page $=6$.

UNESCO. (2018a). Pan-African High-level Conference on Education \#PACE, Nairobi, Kenya, 25-27 April 2018 [undated webnews]. Paris: UNESCO. Retrieved 31 July 2018 from https://en.unesc o.org/education2030-sdg4/PACE2018.

UNESCO. (2018b). Migration, displacement and education: Building bridges not walls. Global Education Monitoring Report 2019. Paris: UNESCO. Retrieved 4 December 2018 from https://en.unesc o.org/gem-report/report/2019/migration.

UNESCO-IIEP (UNESCO International Institute for Educational Planning). (2009). Educational marginalization in national education plans. Background paper prepared for the Education for All Global Monitoring Report 2010. 2010/ED/EFA/MRT/PI/20. Paris: UNESCO-IIEP. Retrieved 31 July 2018 from http://unesdoc.unesco.org/images/0018/001866/186608e.pdf. 
UNESCO-IIEP. (2017). The changing role of higher education. IIEP Newsletter, 12 July 2017. Paris: UNESCO-IIEP. Retrieved 31 July 2018 from http://www.iiep.unesco.org/en/changing-role-highe r-education-4032.

Unterhalter, E. (2019). The many meanings of quality education: Politics of targets and indicators in SDG4. Global Policy, 10(1), 39-51.

Vargas, C. (2017). Lifelong learning from a social justice perspective. Education Research and Foresight Working Papers, no. 21. Paris: UNESCO. Retrieved 24 April 2019 from https://unesdoc.unesc o.org/ark:/48223/pf0000250027.

Verger, A., Fontdevila, C., \& Zancajo, A. (2016). A political economy of global education reform. International Perspectives on Education Reform series. New York: Teachers College Press.

WEF (World Education Forum). (2000). The Dakar framework for action. Education for all: Meeting our collective commitments. Paris: UNESCO. Retrieved 23 May 2019 from: https://unesdoc.unesc o.org/ark:/48223/pf0000121147.

WEF. (2015). Incheon Declaration. Education 2030: Towards inclusive and equitable quality education and lifelong learning for all. UNESCO, World Education Forum 2015 and Ministry of Education, Republic of Korea. Retrieved 31 July 2018 from http://unesdoc.unesco.org/images/0024/00245 6/245656E.pdf.

Publisher's Note Springer Nature remains neutral with regard to jurisdictional claims in published maps and institutional affiliations.

Maren Elfert is Lecturer in Education and Society at the School of Education, Communication \& Society at King's College London. She holds a 2018 National Academy of Education/Spencer postdoctoral fellowship. Before pursuing her doctoral studies, she worked for more than a decade at the UNESCO Institute for Lifelong Learning. Her historical-sociological research focuses on the influence of international organisations on educational ideas and policies. Her book UNESCO's utopia of lifelong learning: An intellectual history was published by Routledge in 2018 . 